\title{
THE EFFECTS OF TAURINE ON PERMETHRIN- INDUCED CYTOGENETIC AND OXIDATIVE DAMAGE IN CULTURED HUMAN LYMPHOCYTES
}

\author{
Hasan TURKEZ ${ }^{1}$ and Elanur AYDIN ${ }^{2}$ \\ Erzurum Technical University, Faculty of Science, Department of Molecular Biology and Genetics, Erzurum, Turkey ${ }^{l}$ \\ Atatürk University, Faculty of Science, Department of Biology, Erzurum, Turkey ${ }^{2}$ \\ Received in May 2011 \\ CrossChecked in May 2011 \\ Accepted in January 2012
}

\begin{abstract}
Permethrin (PM) is a common pyrethroid pesticide used to control pests in agriculture, forestry, horticulture, health care, homes, and textile industry. It is confirmed as a strong mutagen in animals and humans. Taurine (TA) is an amino acid found in mammalian tissues that protects the cell against DNA damage. In this study, we investigated whether supplementation of human lymphocyte cultures with TA (in the concentrations of $25 \mu \mathrm{g} \mathrm{mL}^{-1}, 50 \mu \mathrm{g} \mathrm{mL}^{-1}$ and $100 \mu \mathrm{g} \mathrm{mL} L^{-1}$ ) provided any protection against PM toxicity applied in the concentration of $200 \mu \mathrm{g} \mathrm{mL} \mathrm{m}^{-1}$. Genotoxicity was assessed using the micronucleus (MN) and sister chromatid exchanges (SCE) tests. In addition, we measured the total antioxidant capacity (TAC) and total oxidative stress (TOS) levels in the plasma to determine oxidative effects. PM increased SCE and MN levels and altered TAC and TOS levels. TA alone did not affect SCE and MN levels compared to controls, regardless of the concentration applied. In addition, it increased TAC levels without changing TOS levels. Moreover, it significantly buffered the negative cytogenetic and oxidative effects induced by PM in a clear dose-dependent manner. In conclusion, this study is the first to evidence the beneficial effects of TA against PM-induced DNA and oxidative damages in vitro.
\end{abstract}

KEY WORDS: antioxidant, micronucleus, pesticide, sister chromatid exchanges

Because of widespread use it is important to keep (re)evaluating the genotoxic properties of pesticides $(1,2)$. A number of studies (3-6) has suggested that pesticides such as DDT, cypermethrin, and lambdacyhalothrin produce oxidative stress by generating free radicals and by inducing tissue lipid peroxidation (LPO) in mammals and other organisms. Permethrin (PM), the most popular insecticide among the synthetic pyrethroids, has been used worldwide to control a wide range of insects in agriculture, forestry, public health, and homes (7). Mammalian and nonmammalian bioassays and toxicology studies have confirmed its carcinogenic potential $(8,9)$. PM exposure leads to DNA damage in humans and experimental animals $(1,10,11)$. It induces oxidative damage to purine bases in the heart cells (12) and produces single- and double-strand breaks in striatum cells (13). In addition, PM can cause a genotoxic response through oxidative stress (14).

Much of the current research is focused on finding substances capable of countering the genotoxicity of man-made or natural mutagens. These include various vitamins, propolis, sulphhydryl compounds, and plant products (15-19). Taurine (TA) (2-aminoethanesulfonic acid) is found in high concentrations in various mammalian tissues (20). Sung et al. (21) reported that 
TA suppressed oxidant-induced tissue injuries by stabilising the biomembrane and by scavenging free radicals (21). This has been supported by other studies that associate its protective antioxidant properties with direct scavenging of free radicals and indirect preserving of membrane permeability $(22,23)$. TA has therefore become a promising option to treat chemically induced illnesses $(14,24-27)$. Recent investigations have shown that TA protects cells from the toxic effects of cadmium (Cd), paracetamol, and arsenic (As) that are mediated by free-radical attack (28-31).

This is why we assumed that TA could provide protection against PM-induced genotoxic and oxidative damages. To test this assumption, we treated human lymphocytes with PM and with TA and determined the frequencies of sister chromatid exchanges (SCEs) and micronuclei (MNs), as both assays are widely used in genotoxicity testing and biomonitoring $(32,33)$. In addition, we wanted to see how treatment with PM and TA affected the total antioxidant capacity (TAC) and total oxidative stress (TOS) levels in the plasma.

\section{MATERIAL AND METHODS}

\section{Blood sampling}

Blood was sampled by venipuncture from three healthy non-smoking women aged 22 to 25 years. Blood sampling has been approved by the institutional ethics committee and has been performed according to the Declaration of Helsinki.

\section{Experimental design}

Taurine (TA; $\mathrm{C}_{2} \mathrm{H}_{7} \mathrm{NO}_{3} \mathrm{~S}$; CAS No. 107-35-7; Sigma-Aldrich ${ }^{\circledR}$ Chem. Co. St. Louis, MO, USA) was dissolved in distilled water and tested in the concentrations of $25 \mu \mathrm{g} \mathrm{mL}^{-1}, 50 \mu \mathrm{g} \mathrm{mL}^{-1}$, and $100 \mu \mathrm{g} \mathrm{mL}$. Permethrin (PM; $\mathrm{C}_{21} \mathrm{H}_{20} \mathrm{Cl}_{2} \mathrm{O}_{3}$, CAS No. 52645-53-1; Riedel-de Haen ${ }^{\circledR}$, Seelze-Hannover, Germany) was dissolved in a mixture of $95 \%$ ethanol and distilled water and tested in the concentration of $200 \mu \mathrm{g} \mathrm{mL} \mathrm{m}^{-1}$. These concentrations are based on earlier reports; specifically by Undeger and Basaran (1), who have evidenced the mutagenic effects of PM at $200 \mu \mathrm{g} \mathrm{mL}^{-1}$ while Chesney (34) evidenced the protective effects of TA in the concentrations of $25 \mu \mathrm{g} \mathrm{mL}^{-1}, 50 \mu \mathrm{g} \mathrm{mL}^{-1}$, and $100 \mu \mathrm{g} \mathrm{mL}^{-1}$. The compounds were added to the lymphocyte cultures just before incubation for cytogenetic analysis. Cultures were incubated for $72 \mathrm{~h}$ at $37^{\circ} \mathrm{C}$ according to standard protocols for SCE and MN tests. The blood used for determining TAC and TOS levels was incubated with the tested compounds for $2 \mathrm{~h}$ at $37^{\circ} \mathrm{C}$. Negative control samples were treated with distilled water only. Positive control samples were treated with ascorbic acid $\left(\mathrm{C}_{6} \mathrm{H}_{8} \mathrm{O}_{6}\right.$ CAS No. 50-81-7, Sigma ${ }^{\circledR}$; $\left.10 \mu \mathrm{mol} \mathrm{L}^{-1}\right)$ in the TAC analysis and with hydrogen peroxide $\left(\mathrm{H}_{2} \mathrm{O}\right.$, CAS No. 8007-30-5, Sigma ${ }^{\circledR}$; $\left.25 \mu \mathrm{mol} \mathrm{L}^{-1}\right)$ in the TOS analysis.

\section{SCE assay}

We slightly modified the protocol proposed by Evans and O'Riordan (35). Peripheral blood lymphocyte cultures supplemented with 5-bromo-2'deoxyuridine (Sigma $\AA$ ) were incubated at $37{ }^{\circ} \mathrm{C}$ in complete darkness for $72 \mathrm{~h}$. Microscope slides were prepared in triplicate using the standard procedure, air-dried, and stained according to fluorescence plus Giemsa (FPG) method (36). Scorings of SCE were performed under a light microscope on coded slides. To determine the number of SCEs per cell at least, 25 well-spread, second-division metaphases were analysed as described in previous studies (37-39). To ensure the same scoring criteria (40), all microscopy was performed by a single well-trained observer.

\section{MN assay}

We followed the protocol proposed by Fenech and Morley (41). Cytochalasin B $\left(\right.$ Sigma $\left.^{\circledR}\right)$ was added on hour 44 of cultivation. We used duplicate cultures for each concentration. After incubation, the lymphocytes were fixed and placed directly on slides using a cytospin. Air-dried slides were stained with May Grünwald-Giemsa, coded, and analysed under a light microscope applying the criteria reported by Fenech (42). We examined at least 2000 binucleated lymphocytes per concentration for the presence of one, two, or more micronuclei. Here too the slides were analysed in triplicate.

\section{TAC and TOS analysis}

Plasma samples, obtained from the lymphocyte cultures $2 \mathrm{~h}$ after incubation with PM and TA, were analysed using commercial kits (Rel Assay Diagnostics $^{\circledR}$, Gaziantep, Turkey) for automated Trolox-equivalent total antioxidant capacity (TAC) assay and the total oxidant status (TOS) assay (4346). 
The major advantage of the TAC assay is that it measures the antioxidant capacity of all antioxidants in a biological sample and not just of a single compound (43). In this test, antioxidants in the sample reduce dark blue-green coloured 2,2'-azinobis-(3ethylbenzothiazoline-6-sulfonate (ABTS) radical to its colourless form. The change in absorbance at 660 $\mathrm{nm}$ corresponds to the total antioxidant level in a sample. The assay is calibrated with a stable antioxidant standard solution of vitamin $\mathrm{E}$ analog, (Trolox-equivalent) (44).

The TOS assay used here is based on the oxidation of the ferrous ion-chelator complex to ferric ion $\left(\mathrm{Fe}^{3+}\right)$, which is mediated by oxidants contained in the tested sample. The reaction is further enhanced by other molecules from the reaction medium. The reaction of $\mathrm{Fe}^{3+}$ with chromogen in an acidic medium produces a coloured complex. Its intensity corresponds to the total amount of oxidants in the sample and can be measured spectrophotometrically. The TOS assay is calibrated with hydrogen peroxide and the results are expressed in terms of micromolar hydrogen peroxide equivalent per litre (45).

\section{Statistics}

Statistical analysis was performed using the SPSS software (version 12.0, SPSS, Chicago, IL, USA). The results are expressed as mean \pm standard deviation (S.D.). Groups were compared by one-way analysis of variance followed by Duncan's multiple range test. The level of significance was set at $\mathrm{P}<0.05$.

\section{RESULTS}

Table 1 shows the effects of TA and PM on oxidant status in lymphocyte cultures that were determined by
TAC and TOS analysis. Total antioxidant capacity decreased with the addition of PM. In the positive control ( $10 \mu \mathrm{mol} \mathrm{L}^{-1}$ of ascorbic acid) it was twice as high as in the negative control. Similarly, TA caused a significant and dose-dependent increase in TAC compared to negative control. In addition, TA showed dose-dependent inhibitory effects on the oxidative damage caused in lymphocytes by PM. On the other hand, the positive control showed about a threefold increase in TOS compared to the negative control. PM also increased the TOS level, but TA did not.

Figures 1 and 2 show the anti-genotoxic effects of lymphocyte treatment with TAalone and in combination with PM. Permethrin increased SCE frequency compared to the negative control, while TA alone (in the concentrations of $25 \mu \mathrm{g} \mathrm{mL}^{-1}, 50 \mu \mathrm{g} \mathrm{mL}^{-1}$ and $100 \mu \mathrm{g} \mathrm{mL}^{-1}$ ) did not change it. When given with PM, it significantly reduced SCE frequency compared to lymphocytes treated with PM alone (Figure 1).

Similar effects were observed with MN frequency. It significantly $(\mathrm{p}<0.05)$ increased in lymphocytes treated with PM alone and was unaffected by TA at any of the tested concentrations. In the cells treated with PM and TA together, TA decreased MN frequency compared to the negative control (Figure 2).

\section{DISCUSSION}

Pyrethroid pesticides have recently been reported to cause apoptosis (47), disrupt the endocrine system (48), change nitrogen metabolism (49), increase mitochondrial membrane permeability (50), and alter constitutive nitric oxide release (51). Higher SCE and $\mathrm{MN}$ frequencies and higher TOS plasma levels in our

Table 1 Total antioxidant capacity (TAC) and total oxidative stress (TOS) levels in cultured human lymphocytes simultaneously exposed to permethrin (PM) and taurine (TA).

Different superscripts denote significant differences within each column at the $p<0.05$ level. Values are expressed as means \pm standard deviations of three experiments.

\begin{tabular}{lcc}
\hline \multirow{2}{*}{ Treatment } & TAC & TOS \\
& Trolox Equiv. $/ \mathbf{~ m m o l ~ L ~}^{-\mathbf{1}}$ & $\mathbf{H}_{2} \mathbf{O}_{2}$ Equiv. $/ \boldsymbol{\mu m o l ~ \mathbf { ~ L } ^ { - 1 }}$ \\
\hline Negative control & $6.5 \pm 0.7^{\mathrm{d}}$ & $11.5 \pm 3.2^{\mathrm{a}}$ \\
\hline Positive control & $13.71 \pm 0.94^{\mathrm{g}}$ & $39.25 \pm 4.63^{\mathrm{f}}$ \\
\hline PM & $4.4 \pm 0.7^{\mathrm{a}}$ & $17.2 \pm 4.5^{\mathrm{e}}$ \\
\hline TA1 & $7.6 \pm 0.8^{\mathrm{e}}$ & $11.0 \pm 3.9^{\mathrm{a}}$ \\
\hline TA2 & $8.1 \pm 0.9^{\mathrm{ef}}$ & $11.6 \pm 4.7^{\mathrm{a}}$ \\
\hline TA3 & $8.8 \pm 1.2^{\mathrm{f}}$ & $11.6 \pm 4.4^{\mathrm{a}}$ \\
\hline PM + TA1 & $4.8 \pm 0.7^{\mathrm{ab}}$ & $15.4 \pm 5.1^{\mathrm{d}}$ \\
\hline PM + TA2 & $5.4 \pm 0.8^{\mathrm{b}}$ & $14.2 \pm 5.3^{\mathrm{c}}$ \\
\hline PM + TA3 & $5.9 \pm 0.9^{\mathrm{c}}$ & $12.1 \pm 4.4^{\mathrm{b}}$ \\
\hline
\end{tabular}

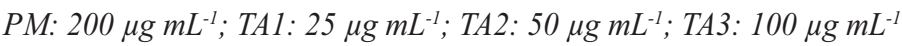




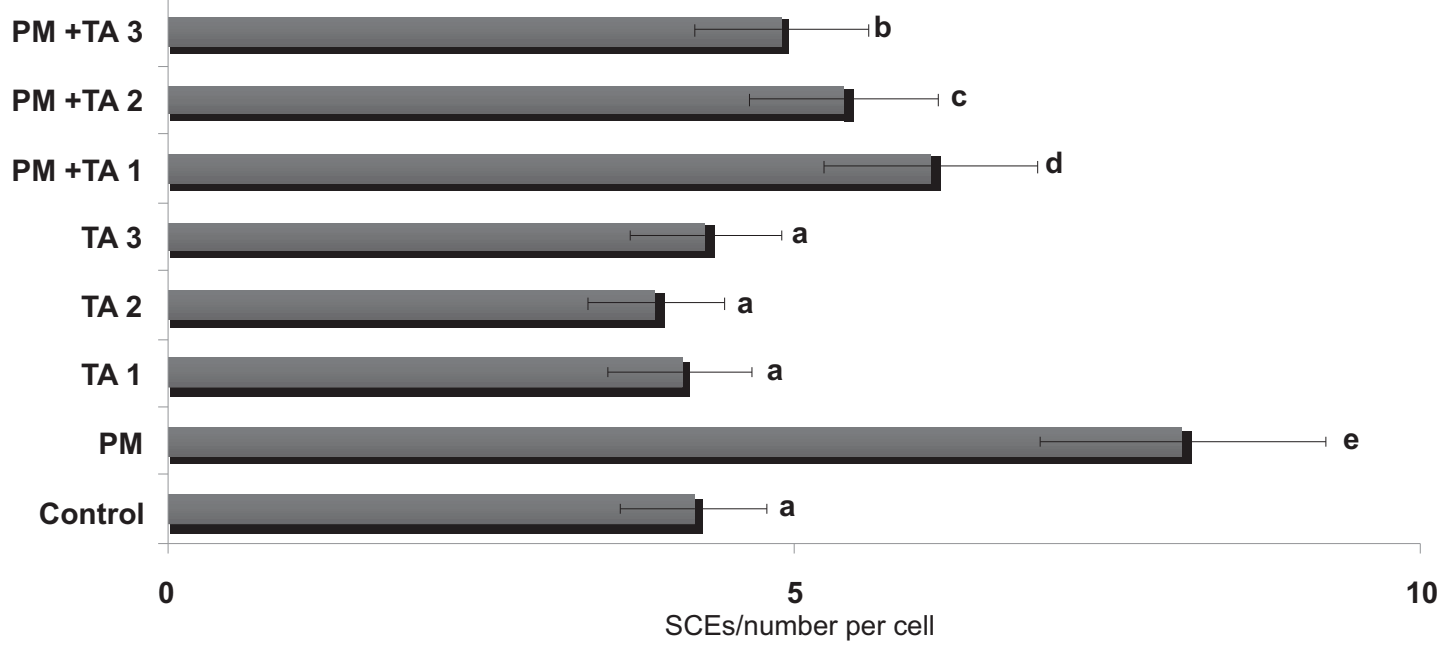

Figure 1 SCE frequency in cultured human lymphocytes simultaneously exposed to permethrin (PM) and taurine (TA). PM:

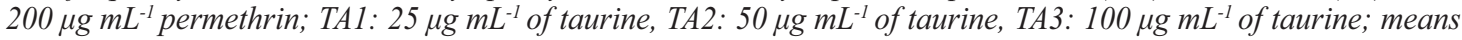
of three measurements marked by different letters differ significantly $(P<0.05)$

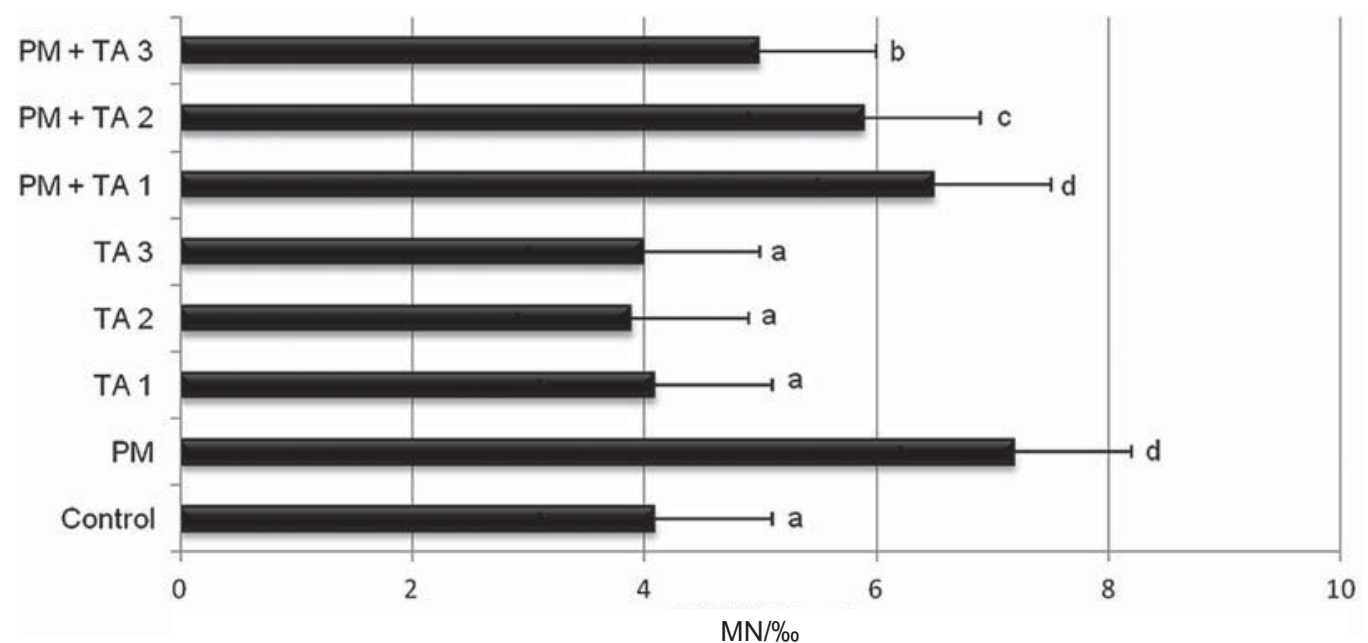

Figure 2 MN frequency (\%) in cultured human lymphocytes simultaneously exposed to permethrin (PM) and taurine (TA). For abbreviations see Figure 1.

study confirm the genotoxic and oxidative action of PM in human lymphocytes. Similarly, earlier studies $(1,52,53)$ reported that $\mathrm{PM}$ induced $\mathrm{MN}$ formation and chromosomal aberrations in human peripheral blood lymphocytes and caused nuclear DNA damage in rats (13). In an experiment with rat adrenal pheochromocytoma (PC12) cells (54), it increased the production of reactive oxygen species (ROS) and malondialdehyde (MDA), which is known as a marker of lipid peroxidation (LPO). At the same time, the authors observed lower antioxidative activity of superoxide dismutase, catalase, and glutathione).

Free radicals damage the cell by, for example, irreversibly damaging lipids in cell membranes and disturbing the structure of proteins. Free radical derivatives damage both the purine-pyrimidine bases and the deoxyribose skeleton in the DNA. The most harmful oxidative lesion of the DNA is 8hydroxyguanine (8-OH-G), which is involved in mutagenesis, carcinogenesis, and aging (55-60).

The increase in SCE and MN frequency observed in our study could be attributed to the pro-oxidative effects of PM. This is supported by decreased TAC and increased TOS levels in PM-treated cells. Recent studies $(12,13)$ also associate oxidative stress induced by PM with DNA damage. Moreover, it is known that toxic oxygen metabolites produced by normal human white blood cells cause the formation 
of SCEs and MNs in cultured mammalian cells (6163). The production of toxic oxygen metabolites in lymphocytes could be set off by a variety of chemicals, including PM.

The results of our study also suggest that TA plays an important protective role. Two hypotheses could explain the modulating effect of TA against PMinduced genotoxicity. The first is that TA acts as an antioxidant in a dose-dependent manner (24). Through antioxidative pathways it seems to modify both target and receptor cell homeostasis (64-66). Plasma and extracellular fluid TA concentrations typically range from $10 \mu \mathrm{mol} \mathrm{L}^{-1}$ to $100 \mu \mathrm{mol} \mathrm{L}^{-1}(67)$. Although this amino acid is not incorporated into proteins, TA intracellular concentrations can reach up to $80 \mathrm{mmol}$ $\mathrm{L}^{-1}$, depending on the tissue type (68). Adding TA does not make it toxic in cells where it is already present in high concentration. Moreover, supplementation with TA (150 mg kg-1 or $\sim 1.87 \mathrm{~g} \mathrm{~L}^{-1}$ ) in a recent study (20) prevented oxidative stress induced by doxorubicin. However, concentrations this high may lead to saturation. Another evidence in favour of the antioxidative action of TA is that the activities of SOD, CAT, and glutathione peroxidase (GSH-Px) normalise in TA-supplemented cultures, and this normalisation reduces LPO levels (69). The second hypothesis is that TA has a cytoprotective role. It is based on the study by Eppler and Dawson (70), who suggest that TA stabilises membrane receptor proteins, reduces protein carbonyl formation, and inhibits oxidative damage to DNA. Both hypotheses have been supported by Cozzi et al. (71), who found that TA protected the DNA by scavenging ROS. Similarly, Du et al. (72) found that TA supplementation had protective effects in high-fat diet-induced obese rats due to its antioxidant nature. In addition, TA showed anti-mutagenic properties in the Salmonella Ames tester strain assay and against aluminium sulphate $(73,74)$.

\section{CONCLUSION}

We have demonstrated for the first time that TA protects human lymphocytes against PM-induced toxicity. TA significantly attenuated DNA damage related to the overproduction of ROS in PM-treated lymphocytes. Supplementation with TA may eventually be useful in individuals who are exposed to synthetic pyrethroids, but the mechanisms of its beneficial effects remain to be elucidated by future studies.

\section{REFERENCES}

1. Undeğer U, Başaran N. Effects of pesticides on human peripheral lymphocytes in vitro: induction of DNA damage. Arch Toxicol 2005;79:169-76.

2. Sheikh SA, Nizamani SM, Jamali AA, Kumbhar MI. Pesticides and associated impact on human health: a case of small farmers in Southern Sindh, Pakistan. J Pharm Nutr Sci 2011;1:82-6.

3. Çömelekoglu Ü, Mazmanci B, Arpaci A. Erythrocyte superoxide dismutase and catalase activity in agriculture works who have been chronically exposed to pesticides. Turkish J Biol 2000;24:483-8.

4. Canales-Aguirre A, Padilla-Camberos E, Gómez-Pinedo U, Salado-Ponce H, Feria-Velasco A, De Celis R. Genotoxic effect of chronic exposure to DDT on lymphocytes, oral mucosa and breast cells of female rats. Int J Environ Res Public Health 2011;8:540-53.

5. El-Demerdash FM. Oxidative stress and hepatotoxicity induced by synthetic pyrethroids-organophosphate insecticides mixture in rat. J Environ Sci Health C Environ Carcinog Ecotoxicol Rev 2011;29:145-58.

6. Shashikumar S, Rajini PS. Alpha-tocopherol ameliorates cypermethrin-induced toxicity and oxidative stress in the nematode Caenorhabdtis elegans. Indian J Biochem Biophys 2011:48:191-6.

7. Zhang SY, Ueyama J, Ito Y, Yanagiba Y, Okamura A, Kamijima M, Nakajima T. Permethrin may induce adult male mouse reproductive toxicity due to cis isomer not trans isomer. Toxicology 2008;248:136-41.

8. Hakoi K, Cabral R, Hoshiya T, Hasegawa R, Shirai T, Ito $\mathrm{N}$. Analysis of carcinogenic activity of some pesticides in a medium-term liver bioassay in the rat. Teratog Carcinog Mutagen 1992;12:269-76.

9. Price RJ, Walters DG, Finch JM, Gabriel KL, Capen CC, Osimitz TG, Lake BG. A mode of action for induction of liver tumors by pyrethrins in the rat. Toxicol Appl Pharmacol 2007;218:186-95.

10. Tisch M, Schmezer P, Faulde M, Groh A, Maier H. Genotoxicity studies on permethrin, DEET and diazinon in primary human nasal mucosal cells. Eur Arch Otorhinolaryngol 2002;259:150-3.

11. Gabbianelli R, Nasuti C, Falcioni G, Cantalamessa F. Lymphocyte DNA damage in rats exposed to pyrethroids: effect of supplementation with vitamins $\mathrm{E}$ and C. Toxicology 2004;203:17-26.

12. Vadhana MS, Nasuti C, Gabbianelli R. Purine bases oxidation and repair following permethrin insecticide treatment in rat heart cells. Cardiovasc Toxicol 2010;10:199207.

13. Falcioni ML, Nasuti C, Bergamini C, Fato R, Lenaz G,

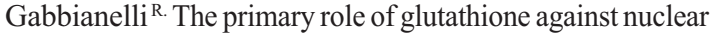
DNA damage of striatum induced by permethrin in rats. Neuroscience 2010;168:2-10.

14. Gabbianelli R, Falcioni ML, Cantalamessa F, Nasuti C. Permethrin induces lymphocyte DNA lesions at both Endo III and Fpg sites and changes in monocyte respiratory burst in rats. J Appl Toxicol 2009;29:317-22.

15. Edenharder R, Worf-Wandelburg A, Decker M, Platt KL. Antimutagenic effects and possible mechanisms of action of vitamins and related compounds against genotoxic 
heterocyclic amines from cooked food. Mutat Res 1999;444:235-48.

16. Rao MV, Chinoy NJ, Suthar MB, Rajvanshi MI. Role of ascorbic acid on mercuric chloride-induced genotoxicity in human blood cultures. Toxicol In Vitro 2001;15:649-54.

17. Türkez H, Yousef MI, Geyikoglu F. Propolis prevents aluminium-induced genetic and hepatic damages in rat liver. Food Chem Toxicol 2010;48:2741-6.

18. Türkez H, Aydin E. The protective role of ascorbic acid on imazalil-induced genetic damage assessed by the cytogenetic tests. Toxicol Ind Health 2012; (in press) (doi:10.1177/074 8233711420471).

19. Turkez H. The role of ascorbic acid on titanium dioxideinduced genetic damage assessed by the comet assay and cytogenetic tests. Exp Toxicol Pathol 2011;63:453-7.

20. Das J, Ghosh J, Manna P, Sil PC. Taurine protects rat testes against doxorubicin-induced oxidative stress as well as $\mathrm{p} 53$, Fas and caspase 12-mediated apoptosis. Amino Acids 2012; (in press) (doi: 10.1007/s00726-011-0904-4).

21. Sung MK, Jeon HS, Park T. Taurine possesses in vitro antimutagenic activity comparable to major antioxidants. J Food Sci Nutr 1999;4:1-83.

22. Wright CE, Tallan HH, Linn YY. Taurine: biological update. Annu Rev Biochem 1986;55:427-53.

23. Timbrell JA, Seabra V, Watereld CJ. The in vivo and in vitro protective properties of taurine. Gen Pharmacol 1995;26:45362.

24. Das J, Ghosh J, Manna P, Sil PC. Taurine provides antioxidant defense against $\mathrm{NaF}$-induced cytotoxicity in murine hepatocytes. Pathophysiology 2008;15:181-90.

25. Ghosh J, Das J, Manna P, Sil PC. Taurine prevents arsenic induced cardiac oxidative stress and apoptotic damage: role of NF-kappa B, p38 and JNK MAPK pathway. Toxicol Appl Pharmacol 2009;240:73-87.

26. Manna P, Sinha M, Sil PC. Taurine plays a beneficial role against cadmium-induced oxidative renal dysfunction. Amino Acids 2009;36:417-28

27. Roy A, Manna P, Sil PC. Prophylactic role of taurine on arsenic mediated oxidative renal dysfunction via MAPKs/NF kappa B and mitochondria dependent pathways. Free Radic Res 2009;43:995-1007.

28. Sinha M, Manna P, Sil PC. Induction of necrosis in cadmium induced hepatic oxidative stress and its prevention by the prophylactic properties of taurine. J Trace Elem Med Biol 2009;23:300-13

29. Acharya M, Lau-Cam CA. Comparison of the protective actions of $\mathrm{N}$-acetylcysteine, hypotaurine and taurine against acetaminophen-induced hepatotoxicity in the rat. J Biomed Sci 2010;17(Suppl 1):S35

30. Das J, Ghosh J, Manna P, Sil PC. Protective role of taurine against arsenic-induced mitochondria-dependent hepatic apoptosis via the inhibition of PKCdelta-JNK pathway. PLoS One 2010;5:e12602.

31. Sevgiler Y, Karaytug S, Karayakar F. Antioxidative effects of n-acetylcysteine, lipoic acid, taurine, and curcumin in the muscle of Cyprinus carpio L. exposed to cadmium. Arh Hig Rada Toksikol 2011;62:1-9.

32. Hovhannisyan GG. Fluorescence in situ hybridization in combination with the comet assay and micronucleus test in genetic toxicology. Mol Cytogenet 2010;3:17.

33. Türkez H, Sisman T. The genoprotective activity of resveratrol on aflatoxin B1-induced DNA damage in human lymphocytes in vitro. Toxicol Ind Health 2012; (in press) (doi:10.1177/0748233711414614).

34. Chesney RW. Taurine: its biological role and clinical implications. Adv Pediatr 1985;32:1-42.

35. Evans HJ, O'Riordan ML. Human peripheral blood lymphocytes for the analysis of chromosome aberrations in mutagen tests. Mutat Res 1975;31:135-48.

36. Perry P, Wolff S. New Giemsa method for the differential staining of sister chromatids. Nature 1974;251:156-8.

37. Türkez H, Toğar B. The genotoxic and oxidative damage potential of olanzapine in vitro. Toxicol Ind Health 2010;26:583-8.

38. Gulten T, Evke E, Ercan I, Evrensel T, Kurt E, Manavoglu O. Lack of genotoxicity in medical oncology nurses handling antineoplastic drugs: effect of work environment and protective equipment. Work 2011;39:485-9.

39. Khaled IA, El-Ansary MS, Saleh AF, Mahmoud OM, Baioumi EA, Bakr HA. Cytogenetic study of the effect of Schistosoma mansoni infection on human peripheral blood lymphocytes and the role of $\beta$-carotene and vitamin $\mathrm{E}$ in modulating this effect. Mol Biol Rep 2011;38:4101-9.

40. Aydin E. The investigation of cytogenetic and oxidative effects of some lichen species located in Erzurum and Artvin cities. [Master's thesis]. Erzurum: Atatürk University, Gradute School of Natural and Applied Sciences, Department of Biology; 2011.

41. Fenech M, Morley AA. Measurement of micronuclei in lymphocytes. Mutat Res 1985;147:29-36.

42. Fenech M. The cytokinesis-block micronucleus technique: a detailed description of the method and its application to genotoxicity studies in human populations. Mutat Res 1993;285:35-44.

43. Kusano C, Ferrari B. Total Antioxidant Capacity: a biomarker in biomedical and nutritional studies. J Cell Mol Biol 2008;7:1-15.

44. Erel O. A novel automated method to measure total antioxidant response against potent free radical reactions. Clin Biochem 2004; 37:112-9.

45. Erel O. A new automated colorimetric method for measuring total oxidant status. Clin Biochem 2005;38:1103-11.

46. Erel O. A novel automated direct measurement method for total antioxidant capacity using a new generation, more stable ABTS radical cation. Clin Biochem 2004;37:277-85.

47. Hossain M M, Richardson JR. Mechanism of pyrethroid pesticide-induced apoptosis: role of calpain and the ER stress pathway. Toxicol Sci 2011;122:512-25.

48. Jin Y, Wang L, Ruan M, Liu J, Yang Y, Zhou C, Xu B, Fu Z. Cypermethrin exposure during puberty induces oxidative stress and endocrine disruption in male mice. Chemosphere 2011;84:124-30.

49. Kumar A, Sharma B, Pandey RS. Cypermethrin induced alterations in nitrogen metabolism in freshwater fishes. Chemosphere 2011;83:492-501.

50. Chen D, Huang X, Liu L, Shi N. Deltamethrin induces mitochondrial membrane permeability and altered expression of cytochrome C in rat brain. J Appl Toxicol 2007;27:36872.

51. Casares FM, Mantione K. Pesticides may be altering constitutive nitric oxide release, thereby compromising health. Med Sci Monit 2006;12:RA235-40. 
52. Barrueco C, Herrera A, Caballo C, de la Peña E Cytogenetic effects of permethrin in cultured human lymphocytes. Mutagenesis 1992;7:433-7.

53. Barrueco C, Herrera A, Caballo C, de la Peña E. Induction of structural chromosome aberrations in human lymphocyte cultures and $\mathrm{CHO}$ cells by permethrin. Teratog Carcinog Mutagen 1994;14:31-8.

54. Hu F, Li L, Wang C, Zhang Q, Zhang X, Zhao M. Enantioselective induction of oxidative stress by permethrin in rat adrenal pheochromocytoma (PC12) cells. Environ Toxicol Chem 2010;29:683-90.

55. Kasai H, Nishimura S. Formation of 8hydroxydeoxyguanosine in DNA by oxygen radicals and its biological significance. In Sies,H. (ed.) Oxidative Stress: Oxidants and Antioxidants. Academic Press, London, 1991; pp. 99-116.

56. Aruoma O I. Free radicals, oxidative stress and antioxidants in human health and disease. J American Oil Chem Soc 1998; 75:199-212.

57. Candan S. Nickel ve oksidative stress. Thezis, Gazi Univercity, Faculty of Medicine, Department of Biochemistry, 2002; Ankara.

58. Cooke M S, Evans M D, Dizdaroğlu M, Lunec J. Oxidative DNA damage: Mechanisms, mutation, and disease. FASEB J (Bethesda, MD) 2003;17:1195-214.

59. Burçak G, Andican G. Oksidative DNA damage and aging. Cerrahpaşa J Med, 2004;35:159-69.

60. Lambeth J D. Nox enzymes and the biology of reactive oxygen. Nat Rev Immunol 2004;4:181-9.

61. Von Recklinghausen U, Hartmann LM, Rabieh S, Hippler J, Hirner AV, Rettenmeier AW, Dopp E. Methylated bismuth, but not bismuth citrate or bismuth glutathione, induces cyto- and genotoxic effects in human cells in vitro. Chem Res Toxicol 2008;21:1219-28.

62. Lewinska A, Wnuk M, Slota E, Bartosz G. The nitroxide antioxidant Tempol affects metal-induced cyto- and genotoxicity in human lymphocytes in vitro. Mutat Res 2008;649:7-14.

63. Tiwari P, Kumar A, Balakrishnan S, Kushwaha HS, Mishra KP. Radiation-induced micronucleus formation and DNA damage in human lymphocytes and their prevention by antioxidant thiols. Mutat Res 2009;676:62-8.

64. Nahashima T, Seto Y, Nakajima T. Calcium associated cytoprotective effect of taurine on the calcium and oxygen paradoxes in isolated rathepatocytes. Liver 1990;10:167-72.

65. Satoh H. Cardioprotective actions of taurine against intracellular and extracellular calcium induced effects. In: Huxtable R, Michalk D, editors. Taurine in Health and Disease. New York (NY): Plenum Press; 1994. p. 181-96.

66. Fennessy FM, Moneley DS, Wang JH, Kelly CJ, BouchierHayes DJ. Taurine and vitamin $\mathrm{C}$ modify monocyte and endothelial dysfunction in young smokers. Circulation 2003;107:410-5.

67. Shuller-Levis G B, Park E. Taurine: new implications for an old amino acid. FEMS Microbiol Lett 2003;226:195-202.

68. Kontny E, Chorazy-Massalska M, Rudnicka W, Marcinkiewicz J, Maśliński W. Cytotoxicity of taurine metabolites depends on the cell type. Adv Exp Med Biol 2006;583:157-71.

69. Pushpakiran G, Mahalakshmi K, Anuradha CV. Taurine restores ethanol-induced depletion of antioxidants and attenuates oxidative stress in rat tissues. Amino Acids 2004;2791-6.

70. Eppler B, Dawson RJr. Cytoprotective role of taurine in a renal epithelial cell culture model. Biochem Pharmacol 2002;63:1051-60.

71. Cozzi R, Ricordy R, Bartolini F, Ramadori L, Perticone P, De Salvia R. Taurine and ellagic acid: two differently-acting natural antioxidants. Environ Mol Mutagen 1995;26:24854.

72. Du H, Zhao X, You JS, Park JY, Kim SH, Chang KJ. Antioxidant and hepatic protective effects of lotus root hot water extract with taurine supplementation in rats fed a high fat diet. J Biomed Sci 2010;17:S39.

73. Laidlaw SA, Dietrich MF, Lamtenzan MP, Vargas HI, Block JB, Kopple JD. Antimutagenic effects of taurine in a bacterial assay system. Cancer Res 1989;49:6600-4.

74. Turkez H, Geyikoglu F. The anti-genotoxic effect of taurine on aluminum sulphate-induced DNA damage in human peripheral lymphocytes. IUFS J Biol 2010;69:25-32. 


\section{Sažetak}

\section{DJELOVANJE TAURINA PROTIV CITOGENETIČKOG I OKSIDATIVNOG OŠTEĆENJA U KULTURAMA LJUDSKIH LIMFOCITA UZROKOVANIH PERMETRINOM}

Permetrin je piretroidni pesticid koji se često rabi za suzbijanje nametnika u poljoprivredi, šumarstvu, povrtlarstvu, zdravstvenoj zaštiti, domovima i tekstilnoj industriji. Poznat je kao snažan mutagen u životinja i ljudi. Taurin je aminokiselina koja se nalazi u tkivu sisavaca i štiti stanicu od oštećenja DNA. Svrha je ovog istraživanja bila saznati hoće li taurin (u koncentracijama od $25 \mu \mathrm{g} \mathrm{mL}^{-1}, 50 \mu \mathrm{g} \mathrm{mL}^{-1}$ te $100 \mu \mathrm{g} \mathrm{mL}^{-1}$ ) zaštititi ljudske limfocite od toksičnoga djelovanja permetrina koji je dodan kulturama u koncentraciji od $200 \mu \mathrm{g} \mathrm{mL} \mathrm{mL}^{-1}$. Genotoksično djelovanje ocijenili smo s pomoću mikronukleus (MN)-testa i testa izmjena sestrinskih kromatida (engl. sister chromatid exchanges, krat. SCE). Da utvrdimo oksidativno djelovanje, izmjerili smo ukupni antioksidativni kapacitet (engl. total antioxidant capacity, krat. TAC) i ukupni oksidativni stres (engl. total oxidative stress, krat. TOS) u plazmi. Permetrin je povećao učestalost SCE i MN te promijenio TAC i TOS. Sam taurin, bez obzira na koncentraciju, nije utjecao na učestalost SCE i $\mathrm{MN}$ u odnosu prema kontroli. Usto je podigao TAC, a da pritom nije utjecao na TOS. Štoviše, značajno je ublažio štetno citogenetičko i oksidativno djelovanje permetrina, a učinkovitost mu je bila izravno povezana s primijenjenom koncentracijom. Ovo je prvo in vitro istraživanje koje je pokazalo povoljno djelovanje taurina protiv oksidacijskoga djelovanja permetrina i oštećenja DNA koje on uzrokuje.

KLJUČNE RIJEČI: antioksidans, izmjene sestrinskih kromatida, mikronukleus-test, pesticidi, TAC, TOS

\section{CORRESPONDING AUTHOR:}

Dr Elanur Aydin

Department of Biology, Faculty of Science, Atatürk

University

25240 Erzurum, Turkey

E-mail: elanuraydinn@gmail.com 